\title{
Morphometry Governs the Dynamics of a Drainage Basin: Analysis and Implications
}

\author{
Atrayee Biswas, ${ }^{1}$ Dipanjan Das Majumdar, ${ }^{2}$ and Sayandeep Banerjee ${ }^{3}$ \\ ${ }^{1}$ Department of Geography, University of Calcutta, 35 B. C. Road, Kolkata 700 019, India \\ ${ }^{2}$ Department of Remote Sensing and GIS, Vidyasagar University, Medinipur 721 102, India \\ ${ }^{3}$ Department of Geology, St. Xavier's College (Autonomous), 5 Mahapalika Marg, Mumbai 400001, India
}

Correspondence should be addressed to Atrayee Biswas; adp.biswas@gmail.com

Received 11 February 2014; Accepted 13 March 2014; Published 7 May 2014

Academic Editor: Biswajeet Pradhan

Copyright (C) 2014 Atrayee Biswas et al. This is an open access article distributed under the Creative Commons Attribution License, which permits unrestricted use, distribution, and reproduction in any medium, provided the original work is properly cited.

\begin{abstract}
Mountainous rivers are the most significant source of water supply in the Himalayan provinces of India. The drainage basin dynamics of these rivers are controlled by the tectonomorphic parameters, which include both surface and subsurface characteristics of a basin. To understand the drainage basin dynamics and their usefulness in watershed prioritisation and management in terms of soil erosion studies and groundwater potential assessment and flood hazard risk reduction in mountainous rivers, morphometric analysis of a Himalayan River (Supin River) basin has been taken as a case study. The entire Supin River basin has been subdivided into 27 subwatersheds and 36 morphometric parameters have been calculated under four broad categories: drainage network, basin geometry, drainage texture, and relief characteristics, each of which is further grouped into five different clusters having similar morphometric properties. The various morphometric parameters have been correlated with each other to understand their underlying relationship and control over the basin hydrogeomorphology. The result thus generated provides adequate knowledge base required for decision making during strategic planning and delineation of prioritised hazard management zones in mountainous terrains.
\end{abstract}

\section{Introduction}

Morphometry is the measurement and mathematical analysis of the configuration of the earth's surface and of the shape and dimension of its landforms [1]. The form and structure of drainage basins and their associated drainage networks are described by their morphometric parameters. Morphometric properties of a drainage basin are quantitative attributes of the landscape that are derived from the terrain or elevation surface and drainage network within a drainage basin. Application of quantitative techniques in morphometric analysis of drainage basins was initially undertaken by Horton et al. [2-8] from topographic maps using manual methods.

Remote sensing and Geographical Information System (GIS) techniques are increasingly being used for morphometric analysis of drainage basins throughout the world [913]. Quantitative techniques have been applied to study the morphometric properties of different drainage basins in India
[14-23]. Several authors have studied morphometric properties of drainage basins as indicators of structural influence on drainage development and neotectonic activity [24-27]. In many studies morphometric analysis has been used to assess the groundwater potentiality of the basins and to locate suitable sites for construction of check dams and artificial recharge structures [28-32]. Watershed prioritisation based on morphometric characteristics has also been carried out and aids in the mapping of high flood potential and erosion prone zones [33-37].

Present study bridges the connection between surface morphometry and subsurface geology of a drainage basin to produce effective information as a part of basin management. So the objective of the present research is to study the morphometric parameters of Supin River basin and to identify the influence of the underlying geology on the morphometric parameters of the basin and finally to generate a substantial knowledge base regarding the relationship between surface 
morphometry and subsurface lithology for integrated basin management.

\section{Drainage Basin Setup}

The Supin River basin is located in Uttarkashi district of Uttarakhand (Figure 1) and situated between $78^{\circ} 10^{\prime}-78^{\circ} 38^{\prime} \mathrm{E}$ and $31^{\circ} 00^{\prime}-31^{\circ} 04^{\prime} \mathrm{N}$. The tributaries of Supin River, such as, Har Ki Dun Gad, Borasu Gad, and Ruinsara Gad, are fed by Jamdar glacier (Figure 2(a)). The basin covers an area of $565.41 \mathrm{~km}^{2}$ and has a perimeter of $190.47 \mathrm{~km}$. The study area has three climatic zones: subtropical $(1,500-$ $1,700 \mathrm{~m})$, temperate $(1,700-3,500 \mathrm{~m})$, and alpine $(>3,500 \mathrm{~m})$. The region receives heavy snowfall between November and March. The rainfall varies from 1,000 to $1,500 \mathrm{~mm}$ annually.

In Garhwal Himalaya, one of the major NW-SE trending thrusts is the Main Central Thrust (MCT). The MCT separates the Greater Himalayan Sequence (GHS) from Lesser Himalayan Sequence (LHS) [38]. The Main Central Thrust (MCT) separates the basin into two halves on its hanging wall (MCT sheet) and footwall sides which represent the Ramgarh Thrust (RT) Sheet [39-44] (Figure 2(b)). The Munsiari Thrust (MT) separates the Wangtu gneiss and Rampur group of the Lesser Himalayan Sequence (LHS) within the RT Sheet [45] (Figure 2(b)). The basin is underlain by rocks belonging to three main geological formations: Martoli, Vaikrita, and Garhwal. The upstream portion of the Supin basin, which is mainly drained by its three major tributaries, namely, Har Ki Dun Gad, Borasu Gad, and Ruinsara Gad, is underlain by granite-gneisses and two mica schists belonging to the MCT sheet. The middle portion of the basin is underlain by rocks consisting of Greater Himalayan Gneisses (Augen gneisses and porphyritic granites) and phyllites, quartzites, and biotite grade schists separated by the Munsiari Thrust (MT), whereas near the mouth of the basin, it consists of leucogranite (Figure 2(c)) [46-48]. The presence of MCT and MT fault zones across the drainage network of the Supin River basin influences the drainage and relief characteristics of the Supin River.

\section{Methodology}

The extraction of drainage network has been done from Shuttle Radar Topographic Mission (SRTM) Digital Elevation Model (DEM) $(90 \mathrm{~m})$ data using TNTmips software environment. The generation of depressionless DEM is always the preparatory step for morphometric analysis of drainage basin. Depressions are data errors or result from the averaging involved in assigning elevation values to cells (pixels) of finite area. These spurious depressions interfere with the correct routing of flow paths during the watershed analysis, especially in areas of low relief. The Watershed process solves this problem by first locating and filling the depressions. This depressionless DEM is used to compute the flow direction and flow accumulation raster. Further simulation of these two raster produces the standard flow paths and subwatersheds.

The Supin River basin has been classified into 27 subwatersheds. Only those watersheds have been considered for this study which includes streams of at least three different orders. Thereafter, 36 morphometric parameters (Table 1) have been computed for the entire Supin basin, as well as for each of the subwatersheds. The morphometric parameters have been evaluated from four different aspects-drainage network, basin geometry, drainage texture, and relief. The different parameters were then correlated to understand how they interact with and influence each other. The reliability of the correlation of determination has been tested with the help of Students' $t$-test and calculated $P$ values. Hierarchical cluster analysis (Euclidean distance) has been used as the measure of association which enables the grouping of the subwatersheds into five major categories according to the four morphometric aspects. Hypsometric curve for the entire Supin River basin has been computed along with hypsometric integral (HI) values for all the subwatersheds.

\section{Results and Discussion}

The Supin River having a length of $40.08 \mathrm{~km}$ drains an area of $17.68 \mathrm{~km}^{2}$ (Table 2). The two major thrusts, that is, MCT and MT, cross the upstream and downstream sections of the basin, respectively. The MCT crosses the basin in northwest-southeast direction with subwatersheds like WS3, WS15, WS16, and WS17 lying on its hanging wall and WS18 and WS19 lying on its footwall. The MT crosses the basin in an east-west direction and WS6, WS8, WS20, WS21, WS26, and WS27 are along the hanging wall of MT whereas WS2, WS22, WS23, WS24, and WS27 are along the footwall of MT. In case of WS4, WS5, and WS7, the northern boundary of the subwatershed nearly coincides with MCT and the southern boundary nearly coincides with MT (Figure 2). The major 5th order tributary (Ruinsara Gad) of the Supin River follows the trend of MCT in the SE part of the drainage basin. Moreover, a few other 4 th and 5th order tributaries also follow the trend of MCT and MT fault zones. These fault zones are usually zones of weak, fractured, and brecciated zones which are easily incised by streams. Along the stream profile of the Supin River, at a few places sudden change in slope $\left(\sim 15^{\circ}\right)$ of the stream has been marked as knick points $(K)$ which are controlled by the dip of MCT and MT fault zones (Figure 2(c)).

In the following section the various morphometric parameters have been discussed with regard to the derived cluster groups (Figure 3).

4.1. Drainage Network. Segmentation and hierarchical ordering of streams is necessary to address the hydrodynamic character of a drainage basin. Stream ordering has been done for Supin River basin following the hierarchical ranking proposed by Strahler [6]. Two 5th order streams of Har Ki Dun Gad and Ruinsara Gad combine to form Supin, the 6 th order stream in the basin (Figure 2(a)). The total stream length of Supin basin is 1,439.204 km (Table 1) of which the 1st and 2 nd order streams constitute $87.05 \%$. The stream length ratio $\left(L_{u r}\right)$ varies from 1.05 to 2.06 and is high for 3 rd and 5 th order streams in the Supin basin (Table 2). With increasing stream order there is a decrease in stream number $\left(N_{u}\right)$ 


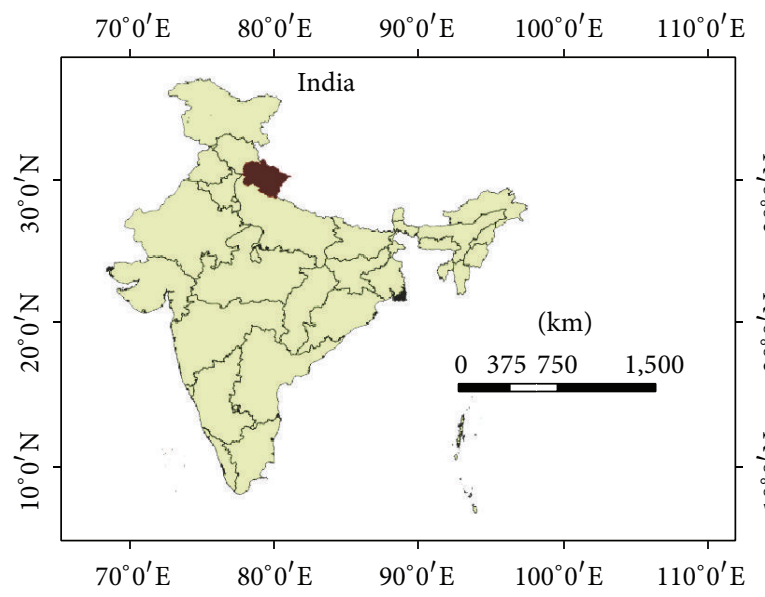

(a)

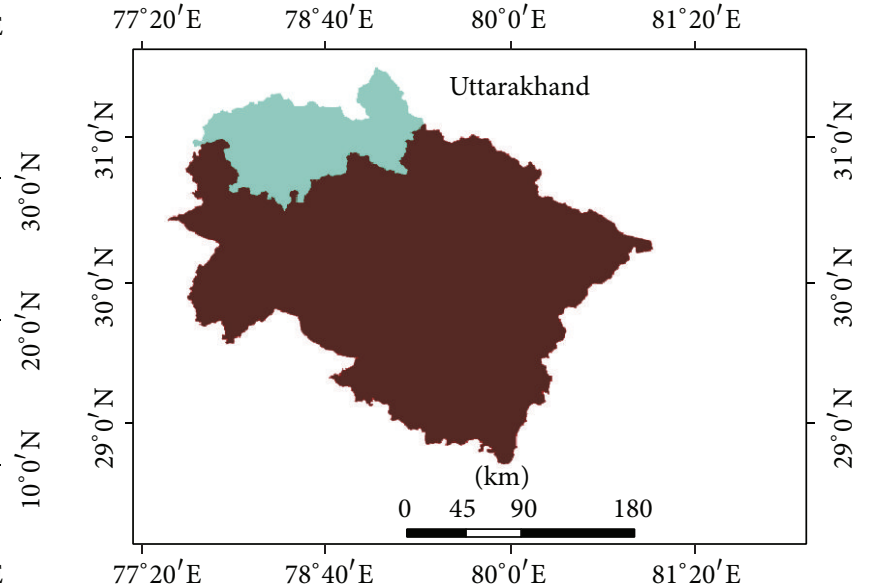

(b)

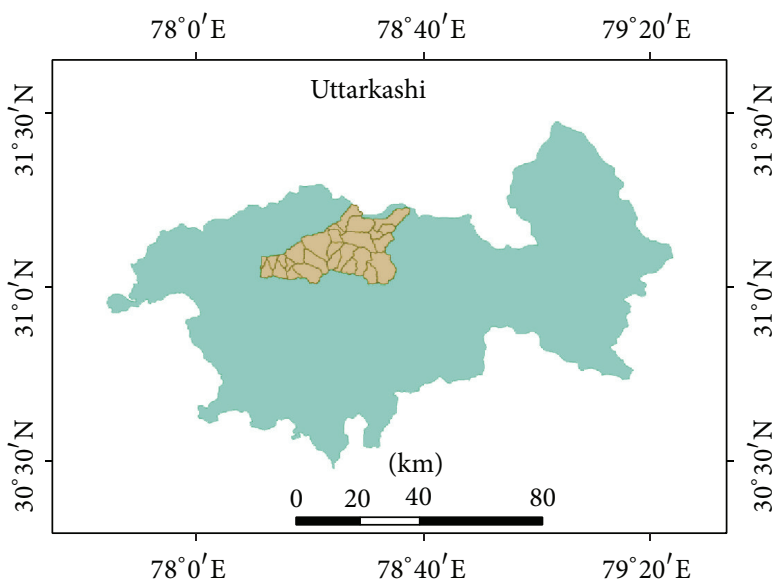

(c)

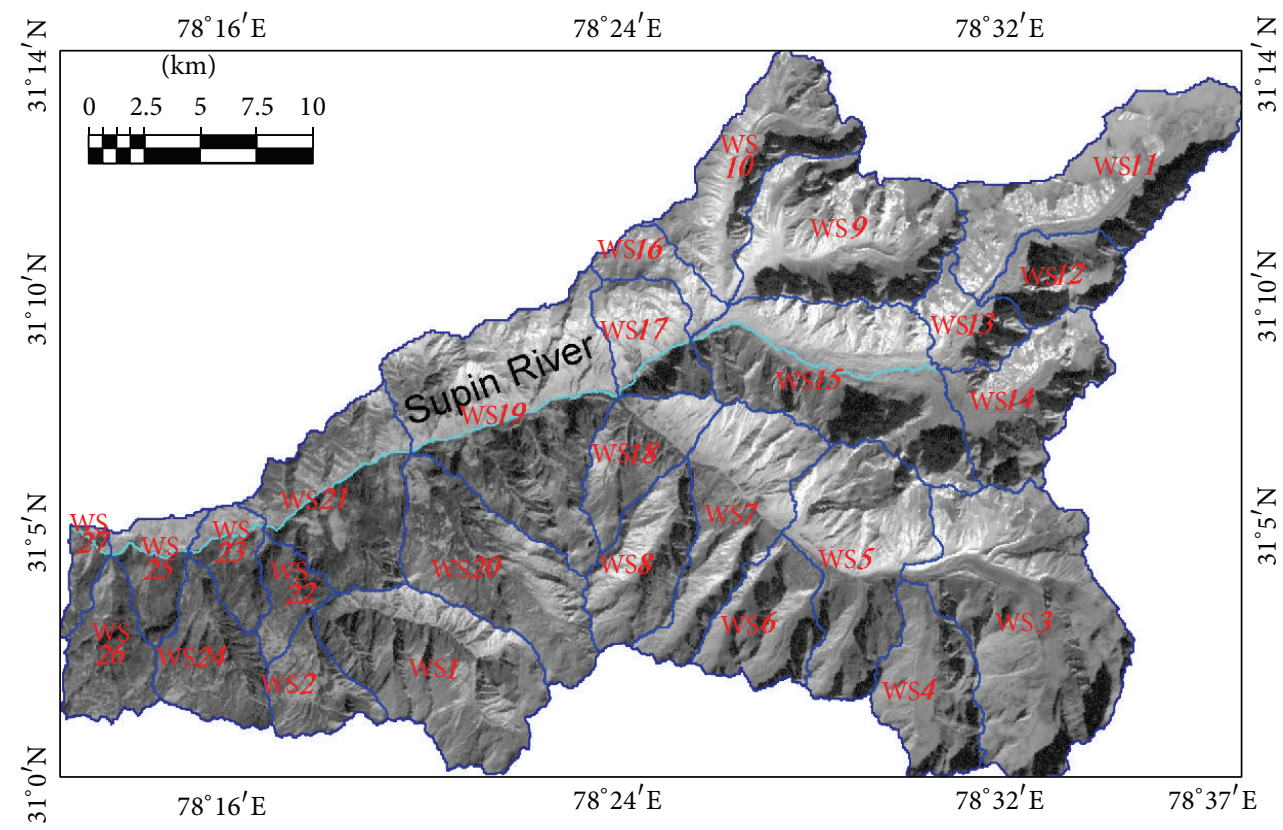

(d)

FIGURE 1: Location map of Supin River basin having an area of $565.406 \mathrm{~km}^{2}$ and a perimeter of $190.466 \mathrm{~km}$. (a) Uttarakhand state in India. (b) Uttarkashi district in Uttarakhand state. (c) Supin River basin in Uttarkashi district. (d) Subwatersheds (27) in Supin River basin. 


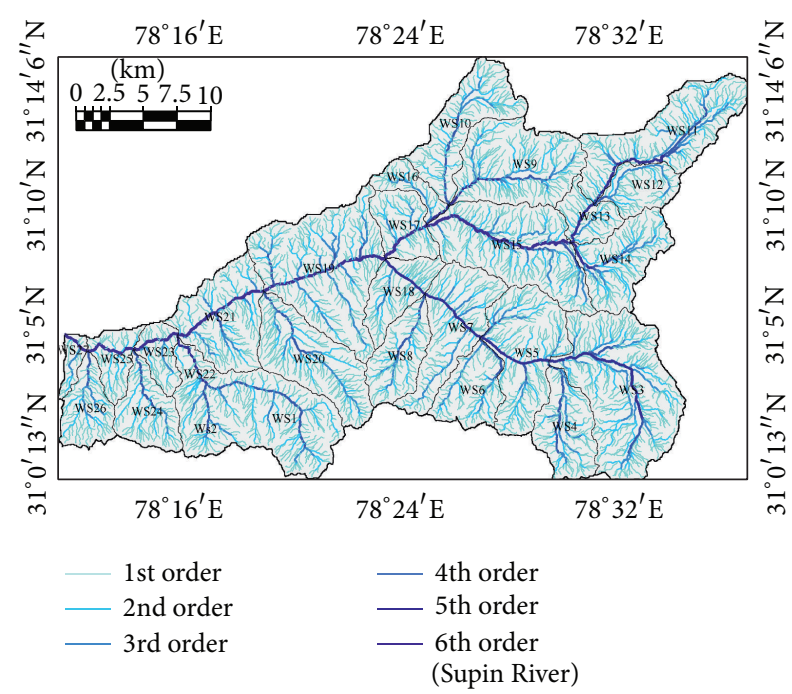

(a)

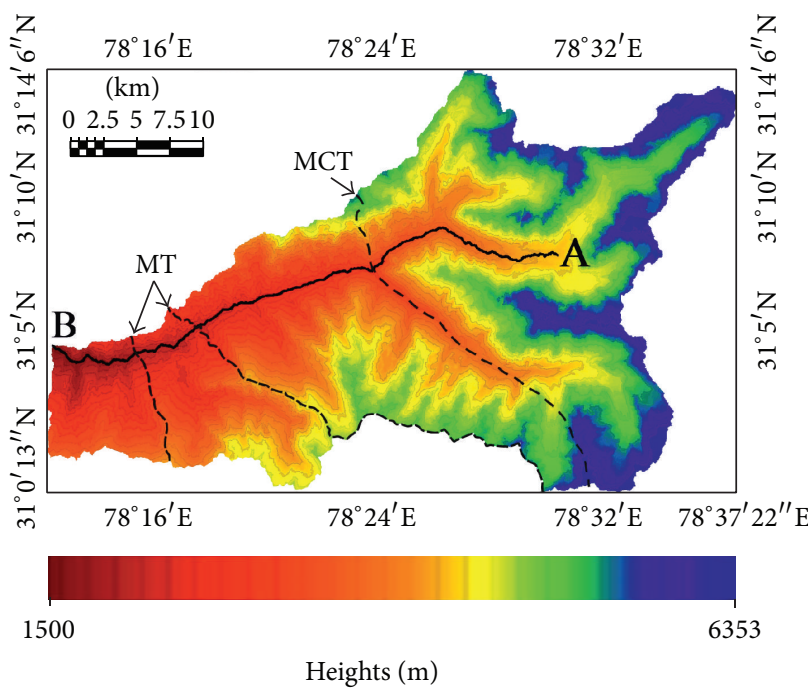

(b)

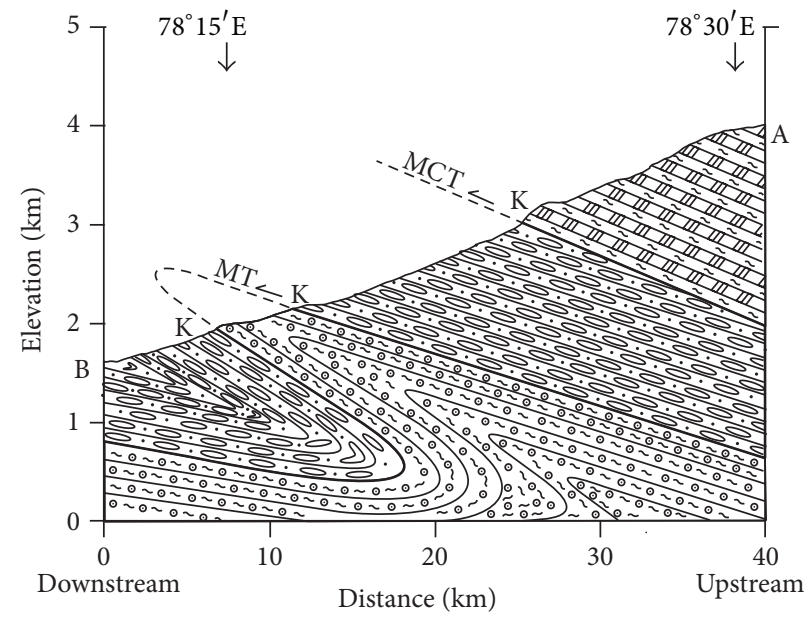

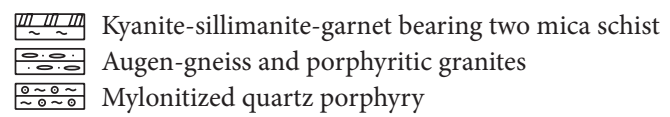

(c)

Figure 2: (a) Stream orders of Supin River basin (ranked according to Strahler [6]). (b) Elevation map of Supin River basin showing fault boundaries-Main Central Thrust (MCT) across the upstream section and Munsiari Thrust (MT) across the downstream section of the Supin River basin. (c) A cross sectional profile along the Supin River showing the approximate disposition of lithology (adopted from Valdiya and Kumar et al. [46, 47]). Knick points are marked as K.

and a simultaneous increase in mean stream length $\left(L_{\text {urm }}\right)$ (Table 2$)$. The RHO coefficient $(\rho)$ and bifurcation ratio $\left(R_{b}\right)$ values for Supin basin range from $0.62-2.10$ (Table 1) and 2 to 5.14 (Table 2), respectively.

The variation of $L_{u r}$ between successive stream orders of Supin River basin is due to the greater number of streams belonging to lower orders indicating that the basin is still in its youthful stage of development (Table 2). High $R_{b}$ values in subwatersheds belonging to C2 and C5 (Table 3) indicate structural control on the development of drainage network. The $\rho$ value signifies the storage capacity of a basin and determines the relationship between drainage density and physiographic development of the basin. Subwatersheds belonging to $\mathrm{C} 4$ and $\mathrm{C} 5$ (Table 3; Figure 3(a)) having high values of $\rho$ are at a greater risk of being eroded by the excess discharge during flood.

4.2. Basin Geometry. Basin shape is controlled by structure, lithology, relief, and precipitation and varies from narrow elongated forms with irregular basin perimeter to circular or semicircular forms. Circularity ratio $\left(R_{c}\right)$ of Supin basin ranges from 0.30 to 0.56 (Table 1 ) with high values in WS1, WS4, WS8, WS9, WS12, WS17, WS21, WS23, and WS24 and low values in WS7, WS10, WS11, WS16, and WS22 (Figure $4(\mathrm{a}))$. High values of form ratio $\left(R_{f}\right)$ and elongation 
TABLE 1: Morphometric parameters calculated for Supin River basin from four aspects—drainage network, basin geometry, drainage texture, and relief characteristics.

\begin{tabular}{|c|c|c|c|c|}
\hline Sl. No & Morphometric parameters & Formulae & Reference & Result (range) \\
\hline \multicolumn{5}{|c|}{ Drainage network } \\
\hline 1 & Stream order $\left(S_{u}\right)$ & Hierarchical rank & {$[4]$} & 1 to 6 \\
\hline 2 & Stream number $\left(N_{u}\right)$ & $N_{u}=N_{1}+N_{2}+\cdots+N_{n}$ & {$[3]$} & 878 \\
\hline 3 & Stream length $\left(L_{u}\right) \mathrm{km}$ & $L_{u}=L_{1}+L_{2}+\cdots+L_{n}$ & {$[6]$} & $1,439.20$ \\
\hline 4 & Stream length Ratio $\left(L_{u r}\right)$ & $L_{u r}=L_{u} / L_{u-1}$ & {$[6]$} & $1.05-2.06$ \\
\hline 5 & Mean stream length ratio $\left(L_{u r m}\right)$ & $\Sigma L_{u r}$ & {$[3]$} & 3.18 \\
\hline 6 & Mean bifurcation ratio $\left(R_{b}\right)$ & $R_{b}=N_{u} / N_{u+1}$ & {$[6]$} & $1.33-5.33$ \\
\hline 7 & Main channel length $\left(C_{l}\right) \mathrm{km}$ & & & 54.52 \\
\hline 8 & Minimum aerial distance $\left(A_{d m}\right) \mathrm{km}$ & & & 43.76 \\
\hline 9 & Channel index $\left(C_{i}\right)$ & $C_{i}=C_{l} / A_{d m}$ & [49] & 1.25 \\
\hline 10 & Rho coefficient $(\rho)$ & $\rho=L_{u r} / R_{b}$ & {$[3]$} & $0.62-2.10$ \\
\hline \multicolumn{5}{|c|}{ Basin Geometry } \\
\hline 11 & Basin length $\left(L_{b}\right) \mathrm{km}$ & & [7] & 44.14 \\
\hline 12 & Basin area $(A) \mathrm{km}^{2}$ & & [7] & 565.41 \\
\hline 13 & Basin perimeter $(P) \mathrm{km}$ & & [7] & 190.47 \\
\hline 14 & Form ratio $\left(F_{f}\right)$ & $F_{f}=A / L_{b}^{2}$ & {$[2]$} & $0.04-0.73$ \\
\hline 15 & Elongation ratio $\left(R_{e}\right)$ & $R_{e}=2 / L_{b} *(A / \pi)^{0.5}$ & [7] & $0.22-0.97$ \\
\hline 16 & Texture ratio $\left(R_{t}\right)$ & $R_{t}=N_{1} / P$ & [7] & $0.27-1.88$ \\
\hline 17 & Circularity ratio $\left(R_{c}\right)$ & $R_{c}=4 \pi A / P^{2}$ & [49] & $0.30-0.56$ \\
\hline 18 & Drainage texture $\left(D_{t}\right)$ & $D_{t}=N_{u} / P$ & {$[3]$} & $0.44-2.55$ \\
\hline 19 & Compactness coefficient $\left(C_{c}\right)$ & $C_{c}=0.2841 * P / A^{0.5}$ & {$[50]$} & $1.34-1.84$ \\
\hline 20 & Fitness ratio $\left(R_{f}\right)$ & $R_{f}=C_{l} / P$ & [51] & 1.92 \\
\hline 21 & Wandering ratio $\left(R_{w}\right)$ & $R_{w}=C_{l} / L_{b}$ & {$[52]$} & 6.01 \\
\hline 22 & Watershed eccentricity $(\tau)$ & $\tau=\left[\left(\left|L_{\mathrm{cm}}{ }^{2}-W_{\mathrm{cm}}{ }^{2}\right|\right)\right]^{0.5} / W_{\mathrm{cm}}$ & {$[53]$} & 0.88 \\
\hline \multicolumn{5}{|c|}{ Drainage texture analysis } \\
\hline 23 & Stream frequency $\left(F_{s}\right)$ & $F_{s}=N_{u} / A$ & {$[2]$} & $1.53-2.90$ \\
\hline 24 & Drainage density $\left(D_{d}\right) \mathrm{km} / \mathrm{kms}^{2}$ & $D_{d}=L_{u} / A$ & {$[2]$} & $1.92-3.06$ \\
\hline 25 & Constant of channel maintenance $(C)\left(\mathrm{kms}^{2} / \mathrm{km}\right)$ & $C=1 / D_{d}$ & [7] & $0.33-0.52$ \\
\hline 26 & Drainage intensity $\left(D_{i}\right)$ & $D_{i}=F_{s} / D_{d}$ & {$[54]$} & $0.79-1.11$ \\
\hline 27 & Infiltration number $\left(I_{f}\right)$ & $I_{f}=F_{s} * D_{d}$ & {$[54]$} & $2.94-8.61$ \\
\hline 28 & Length of overland flow $\left(L_{g}\right) \mathrm{km}$ & $L_{g}=A / 2 * L_{u}$ & [3] & $0.16-0.26$ \\
\hline \multicolumn{5}{|c|}{ Relief characteristics } \\
\hline 29 & Height of basin mouth $(z) \mathrm{m}$ & & & 1,543 \\
\hline 30 & Maximum height of the basin $(Z) \mathrm{m}$ & & & 5,839 \\
\hline 31 & Total basin relief $(H) \mathrm{m}$ & $H=Z-z$ & {$[4]$} & 4296 \\
\hline 32 & Relief ratio $\left(R_{h}\right)$ & $R_{h}=H / L_{b}$ & {$[7]$} & $0.07-0.44$ \\
\hline 33 & Absolute relief $\left(R_{a}\right) \mathrm{m}$ & & & 5839 \\
\hline 35 & Ruggedness number $\left(R_{n}\right)$ & $R_{n}=D_{d} *(H / 1000)$ & {$[6]$} & $3.02-6.44$ \\
\hline 36 & Dissection index $\left(D_{i s}\right)$ & $D_{i s}=H / R_{a}$ & [55] & $0.27-0.61$ \\
\hline
\end{tabular}

TABLE 2: Stream order-wise frequency distribution of number of streams along with their mean stream length, drainage area, and bifurcation ratio.

\begin{tabular}{lccccc}
\hline $\begin{array}{l}\text { Stream order } \\
\left(s_{u}\right)\end{array}$ & $\begin{array}{c}\text { Number of } \\
\text { streams }\left(N_{u}\right)\end{array}$ & $\begin{array}{c}\text { Mean stream } \\
\text { length }(\mathrm{km})\left(L_{s m}\right)\end{array}$ & $\begin{array}{c}\text { Stream length ratio } \\
\left(L_{u r}\right)\end{array}$ & $\begin{array}{c}\text { Drainage area } \\
\left(\mathrm{km}^{2}\right)\end{array}$ & $\begin{array}{c}\text { Bifurcation ratio } \\
\left(R_{b}\right)\end{array}$ \\
\hline 1 & 677 & 2.85 & & 349.05 & \\
2 & 155 & 2.99 & 1.05 & 100.29 & 4.37 \\
3 & 36 & 6.15 & 2.06 & 50.32 & 4.31 \\
4 & 7 & 11.60 & 1.89 & 15.90 & 5.14 \\
5 & 2 & 23.23 & 2.00 & 22.46 & 3.50 \\
6 & 1 & 40.08 & 1.73 & 17.68 & 2.00 \\
\hline
\end{tabular}




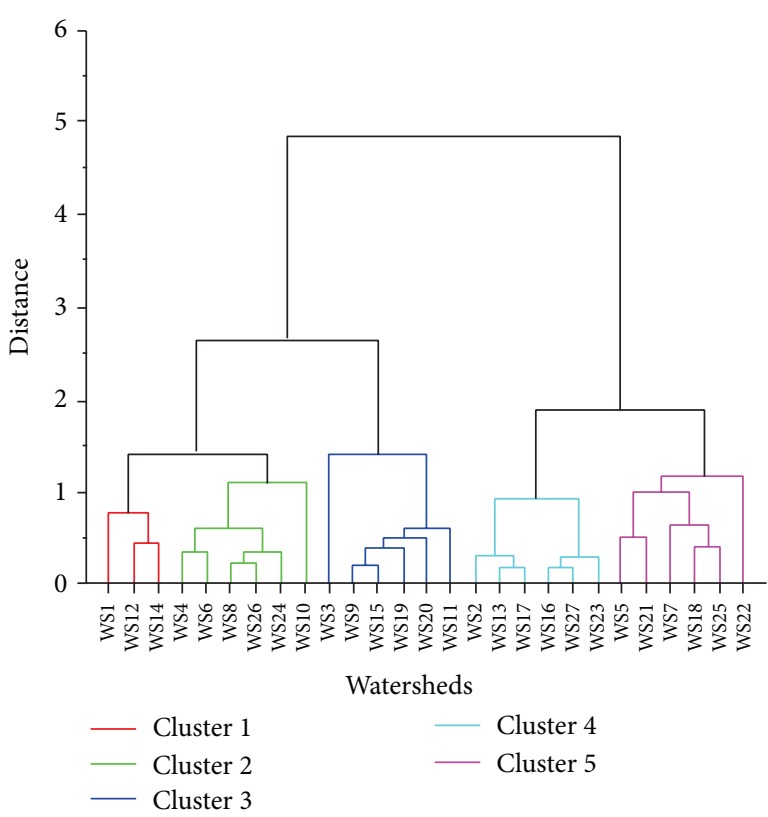

(a)

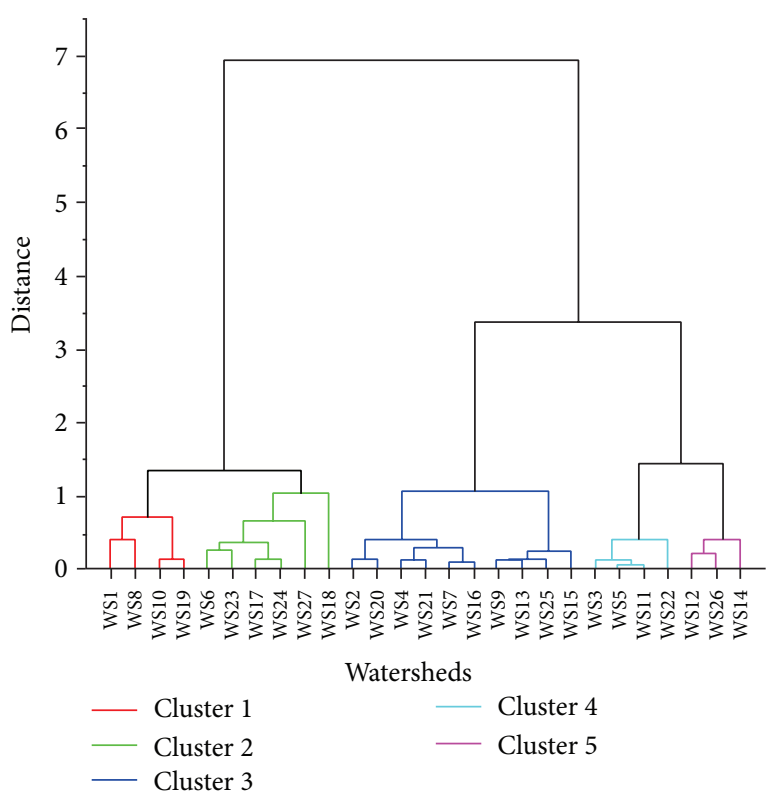

(c)

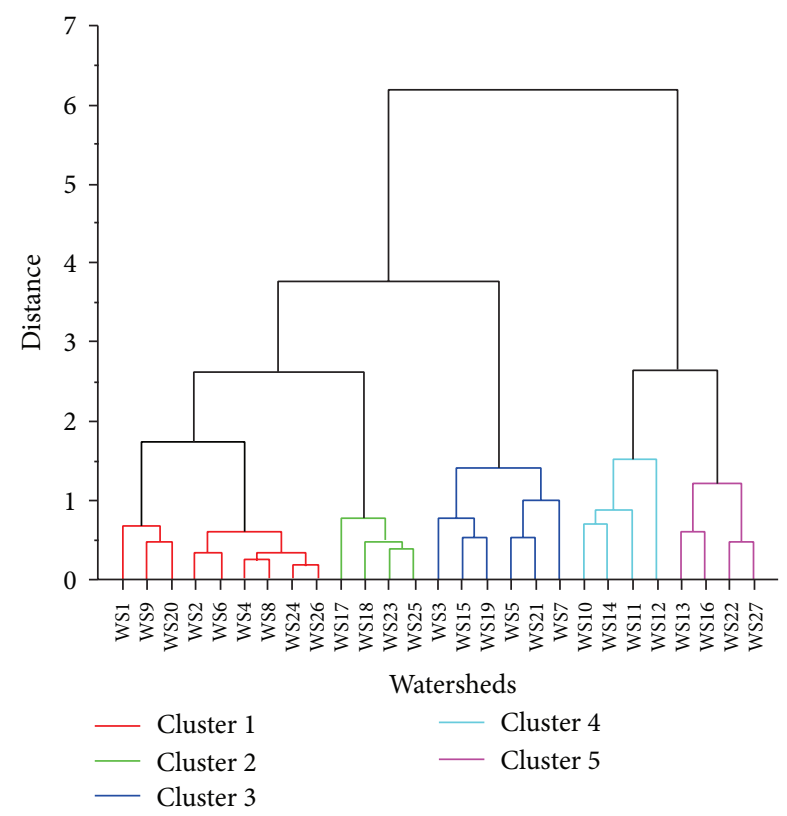

(b)

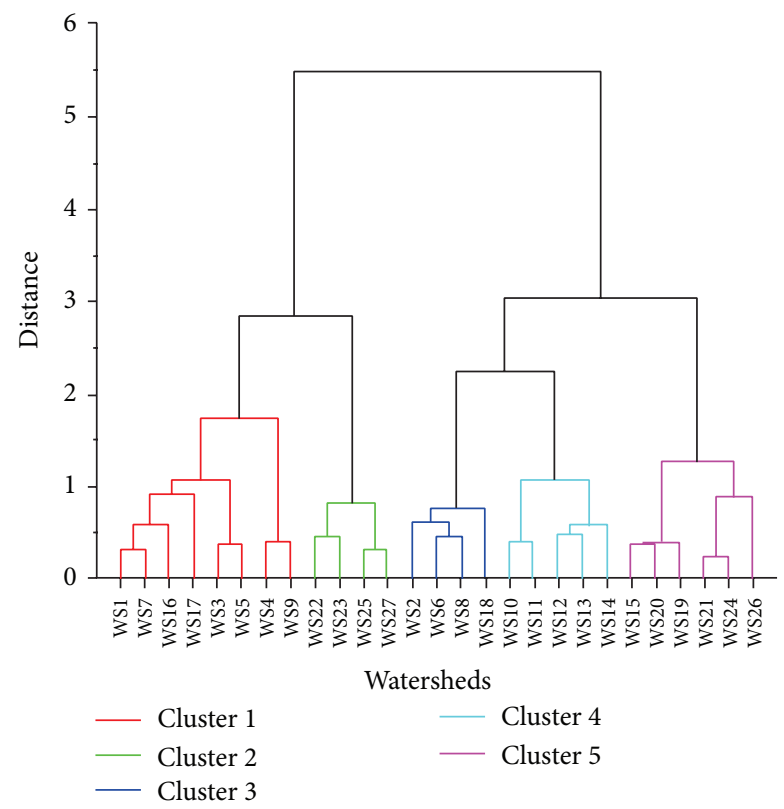

(d)

FIGURE 3: Dendrogram showing groups having similar properties: (a) related to drainage network, (b) related to basin geometry, (c) related to drainage texture analysis, and (d) related to relief characteristics.

ratio $\left(R_{e}\right)$ are found in WS3, WS5, WS17, WS19, WS21, WS23, and WS25, whereas low values are found in WS11, WS12, WS13, WS14, and WS16 (Figures 4(b) and 4(c)). The relative spacing of channels in a drainage basin is expressed by texture ratio $\left(R_{t}\right)$ and drainage texture $\left(D_{t}\right)$. The $R_{t}$ and $D_{t}$ values of Supin basin range from 0.27 to 1.88 and 0.44 to 2.55 , respectively (Table 1 ). High values of $D_{t}$ are found in subwatersheds located in the upper reaches of the basin, whereas low $D_{t}$ values are found in subwatersheds located near the mouth of the basin (Figure $4(\mathrm{~d})$ ).
$R_{c}$ bears a strong negative relationship with compactness coefficient $\left(C_{c}\right)$, whereas $F_{f}$ has a positive relationship with $R_{e}$ (Table 4) [28]. Low values of $R_{c}$ (C4 and C5) (Table 3; Figure 3(b)) are associated with high relief and steep slopes and imply the youthful nature of these subwatersheds. The subwatersheds belonging to C1, C2, and C3 (Figure 3(b)) having high values of $R_{c}, F_{f}, R_{e}, R_{t}$, and $D_{t}$ and low values of $C_{c}$ are more circular in shape than those belonging to $C 4$ and C5 (Table 3). Although the circular subwatersheds are more efficient in the discharge of run-off [56], they are at 


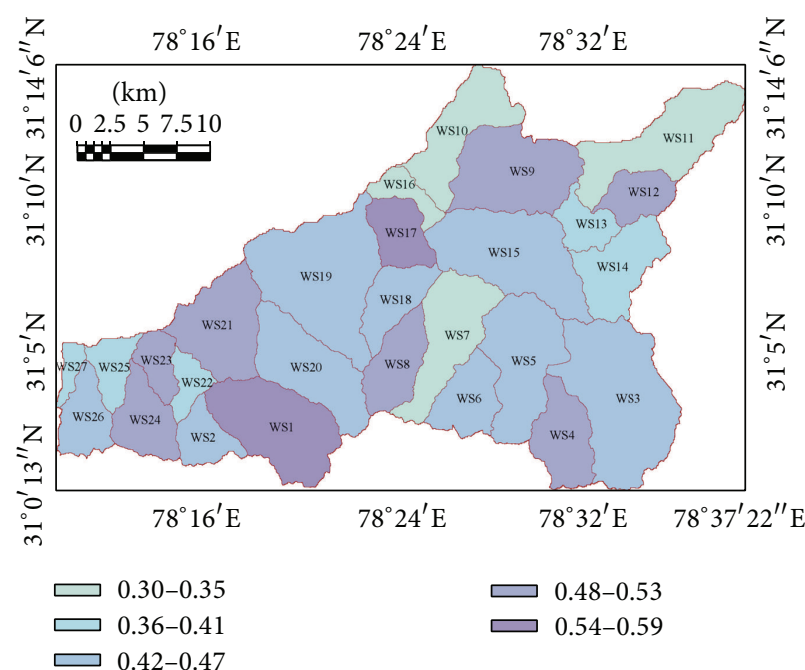

(a)

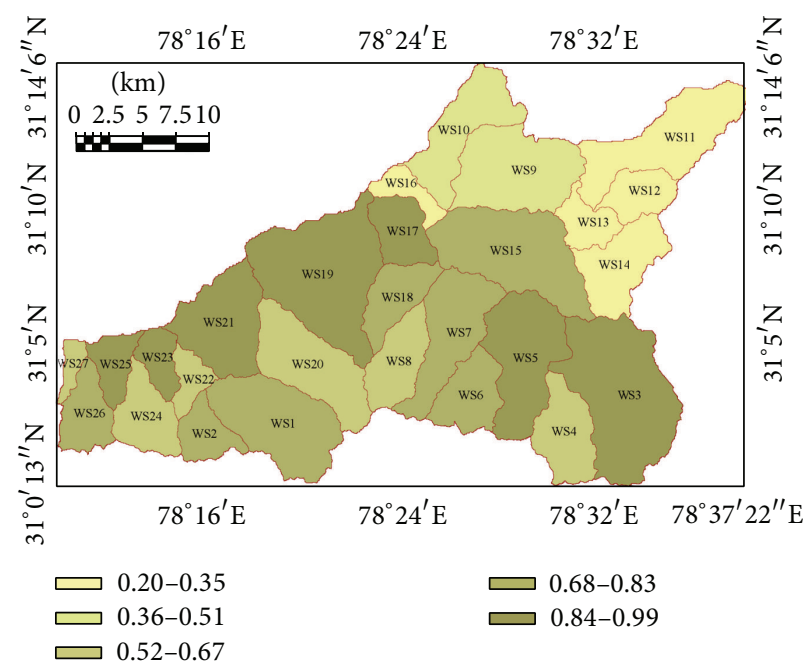

(c)

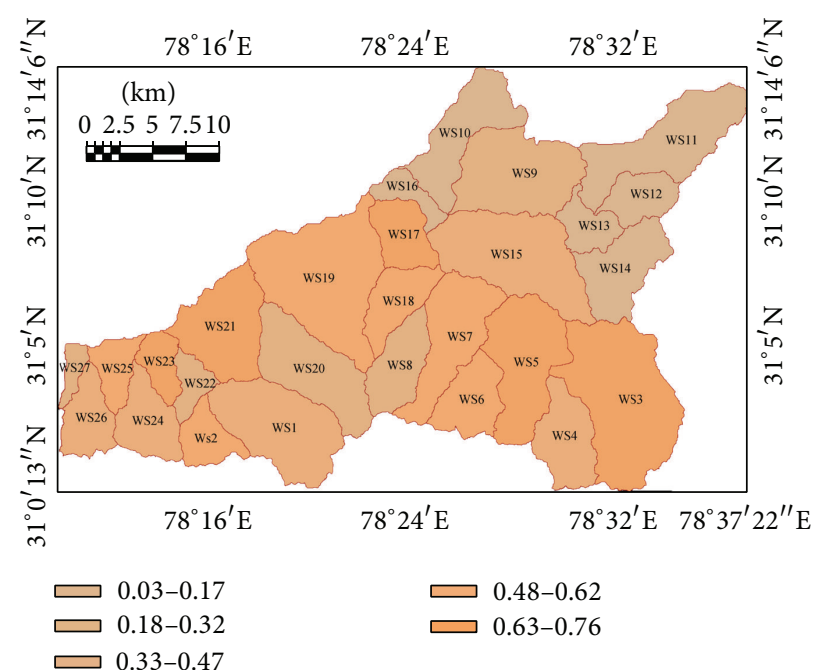

(b)

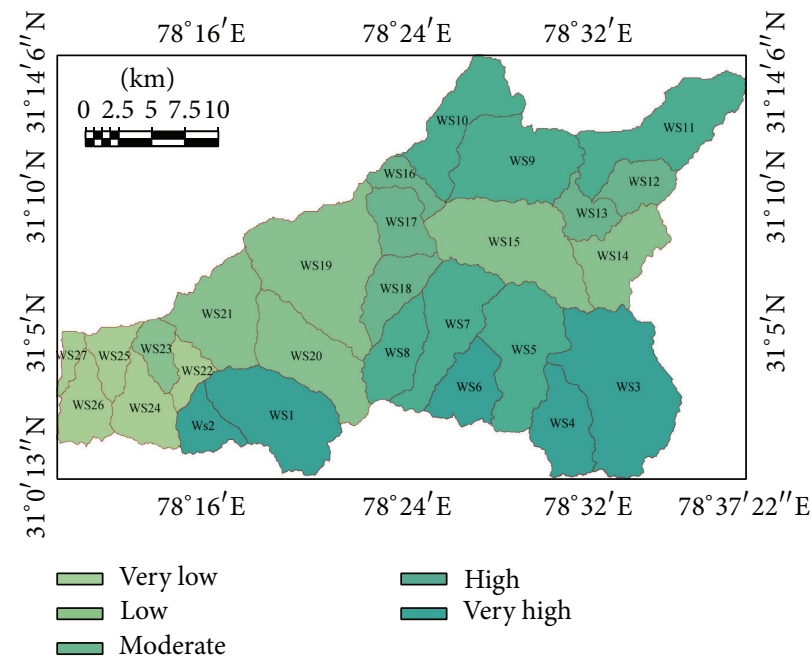

(d)

Figure 4: Map showing response of various basin geometry parameters in subwatersheds of Supin River basin. (a) Circularity ratio $\left(R_{c}\right)$. (b) Form ratio $\left(F_{f}\right)$. (c) Elongation ratio $\left(R_{e}\right)$. (d) Drainage texture $\left(D_{t}\right)$.

greater risk from flood hazard because they have a very short lag time and high peak flows than the elongated basins [57]. The elongated subwatersheds, on the other hand, have low side flow for shorter duration and high main flow for longer duration and are less susceptible to flood hazard.

4.3. Drainage Texture Analysis. Texture indicates the amount of landscape dissection by a channel network and includes stream frequency $\left(F_{s}\right)$, drainage density $\left(D_{d}\right)$, constant of channel maintenance $(C)$, length of overland flow $\left(L_{g}\right)$ and infiltration number $\left(I_{f}\right)$. High values of $F_{s}$ and $D_{d}$ are found in WS3, WS5, WS11 WS14, WS22, and WS25, whereas low values of $F_{s}$ and $D_{d}$ are found in WS1, WS6, WS18, WS23, and WS27 (Figures 5(a) and 5(b)). The $C$ value of Supin basin varies from 0.33 to 0.52 (Table 1 ). The $L_{g}$ value of Supin basin ranges from 0.16 to 0.26 and $I_{f}$ value ranges from 2.94 to 8.61 (Table 1). Low $L_{g}$ values and high $I_{f}$ values are found in WS3,
WS5, WS11, WS12, WS14, and WS22 (Figures 5(c) and 5(d)) which have corresponding high $F_{s}$ and $D_{d}$ values (Figures 5(a) and 5(b)).

$F_{s}$ and $D_{d}$ provide a numerical measurement of landscape dissection and run-off potential [16] and bears a negative relationship with $L_{g}$ and $I_{f}$ (Table 4). Subwatersheds belonging to $\mathrm{C} 3, \mathrm{C} 4$, and $\mathrm{C} 5$ (Table 3; Figure 3(c)) with low values of $L_{g}$ and $C$ have developed numerous drainage lines on the surface. The high values of $F_{s}$ and $D_{d}$ in these subwatersheds maybe due to high relief, steep slopes, and also low permeability of the underlying rocks.

4.4. Relief Characteristics. The relief properties in morphometric analysis bring into consideration the influence of aspect and height over a large basin area. Relief ratio $\left(R_{h}\right)$, ruggedness number $\left(R_{n}\right)$, and dissection index $\left(D_{i s}\right)$ indicate the erosion potential of the processes operating within a 


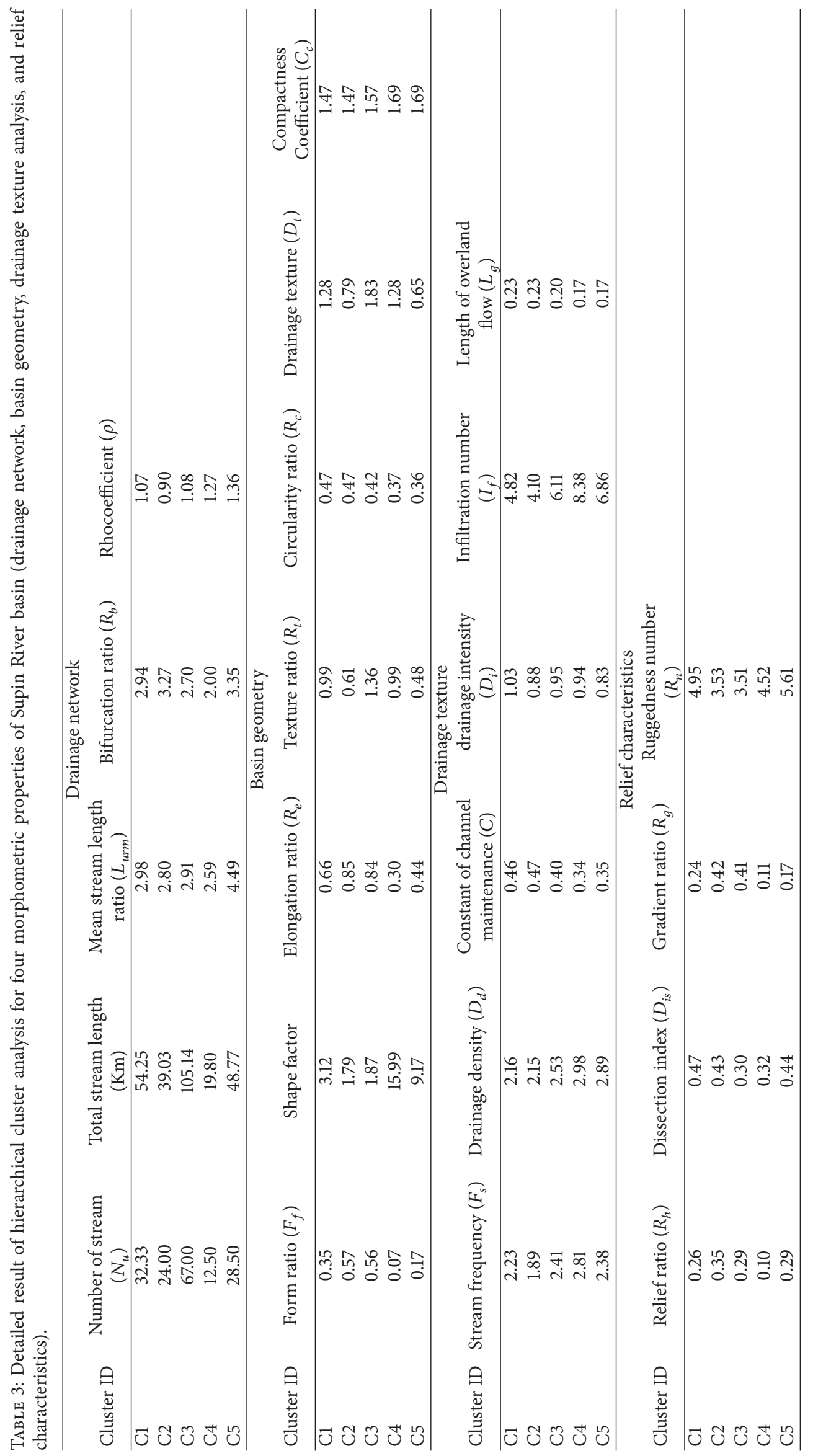




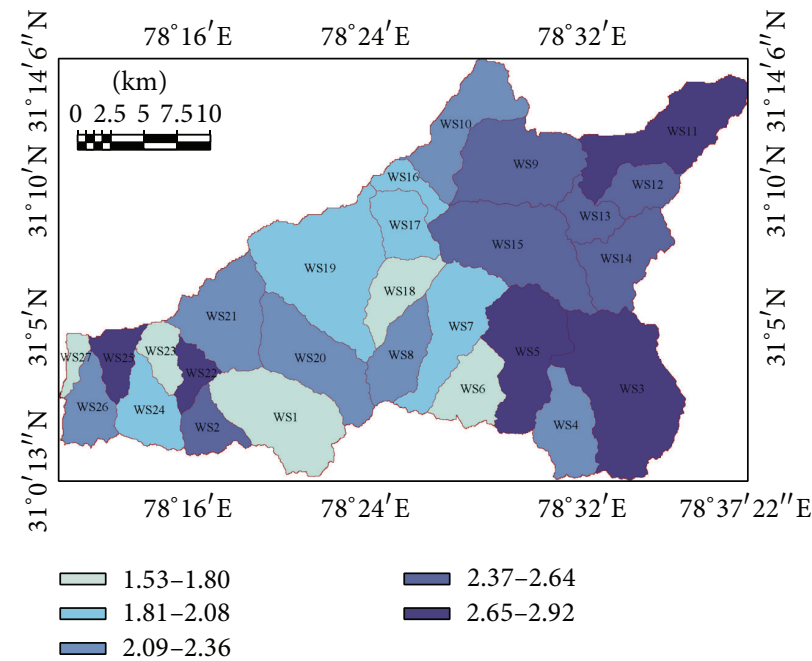

(a)

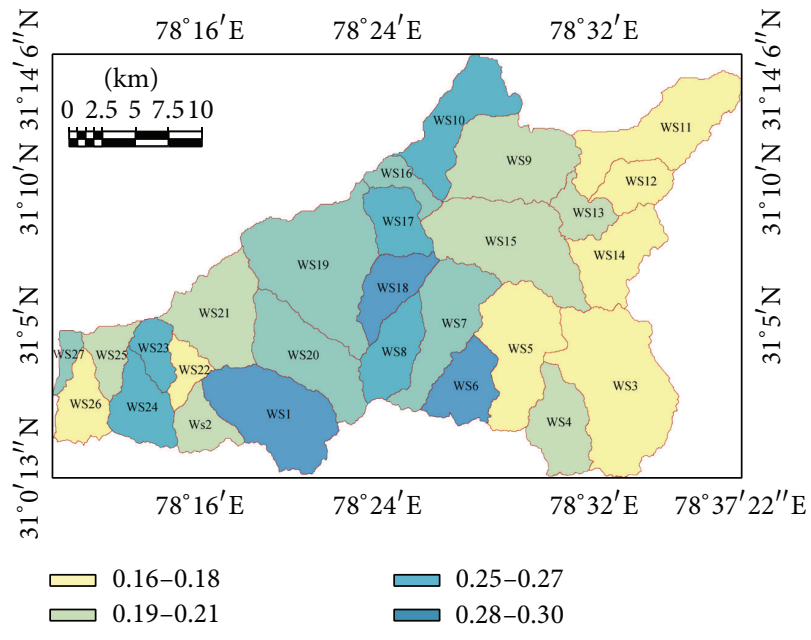

(c)

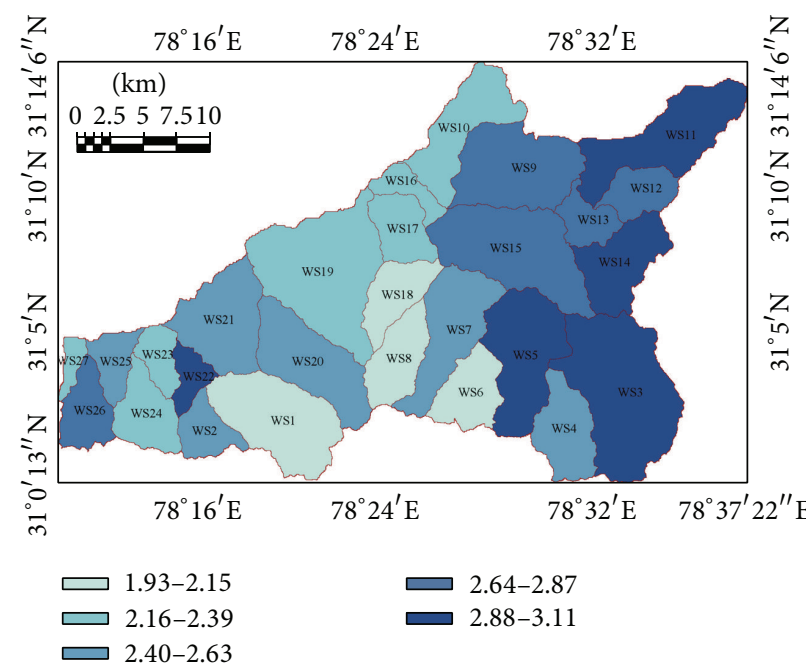

(b)

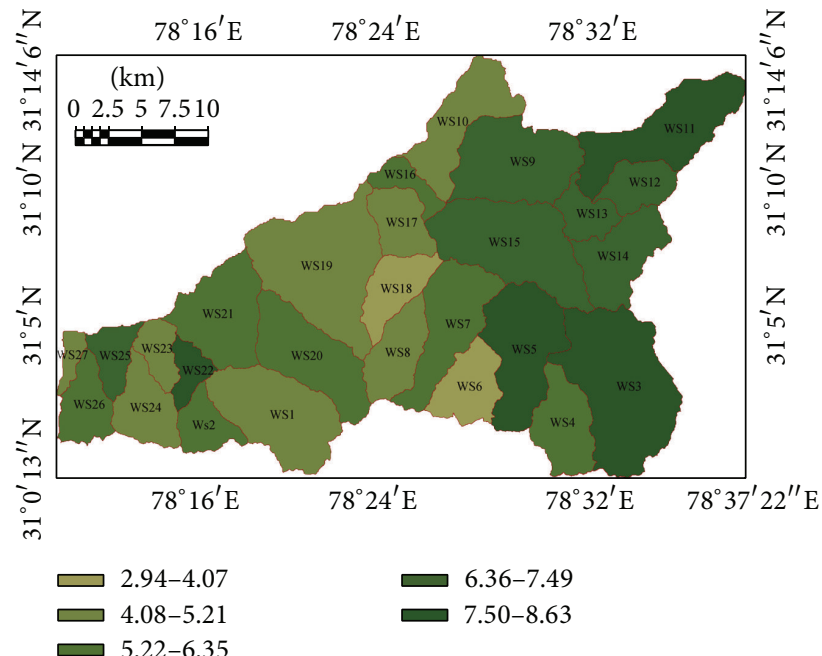

(d)

FiguRE 5: Map showing response of various drainage texture parameters in subwatersheds of Supin River basin. (a) Stream Frequency $\left(F_{s}\right)$. (b) Drainage Density $\left(D_{d}\right)$. (c) Length of overland flow $\left(L_{g}\right)$. (d) Infiltration Number $\left(I_{f}\right)$.

drainage basin. The total basin relief $(Z-z)$ of Supin basin is $4,296 \mathrm{~m}$ (Table 1). The $R_{h}$ value of Supin basin ranges from 0.07-0.44 with high values in WS2, WS5, WS17, WS19, WS21, WS23, WS24, WS25, WS26, and WS27 and low values in WS1, WS9, WS10, WS11, WS12, WS13, and WS14 (Figure 6(a)). High values of $R_{n}$ and $D_{i s}$ are found in WS3, WS4, WS5, WS7, WS9, WS19, and WS20 which indicates the steepness of slope and high degree of dissection of these subwatersheds, whereas low values are found in WS10, WS11, WS12, WS13, and WS14 (Figures 6(b) and 6(c)). $R_{h}$ is related to the channel gradient and has a negative relationship with basin length (Table 4). Subwatersheds having high values of $D_{t}(\mathrm{C} 3$ in Figure 3(b)) also have high values of $R_{n}(\mathrm{Cl}$ and $\mathrm{C} 5$ in Figure 3(d)) since $R_{n}$ has a positive correlation with $D_{t}$ (Table 4 ). The low $D_{i s}$ of Supin basin (0.27-0.61) indicates that the basin is moderately dissected (Table 1).
4.5. Hypsometry Analysis. Hypsometric curve of a drainage basin represents the relative proportion of watershed area below or above a given elevation. It is a measure of the erosional state or geomorphic age of a drainage basin as it represents the mass of drainage basin remaining above a basal plane of reference. Convex hypsometric curves indicate youthful stage, S-shaped curves indicate a mature stage, and concave curves indicate peneplain stage [5]. Here the hypsometric curve has been treated as a cumulative probability distribution and statistical moments have been used to describe the curve quantitatively [58]. The hypsometric curve has been derived by fitting a 5th order polynomial function which is as follows:

$$
\begin{aligned}
f(x)= & A_{0}+A_{1} * x+A_{2} * x^{2}+A_{3} * x^{3} \\
& +A_{4} * x^{4}+A_{5} * x^{5} .
\end{aligned}
$$




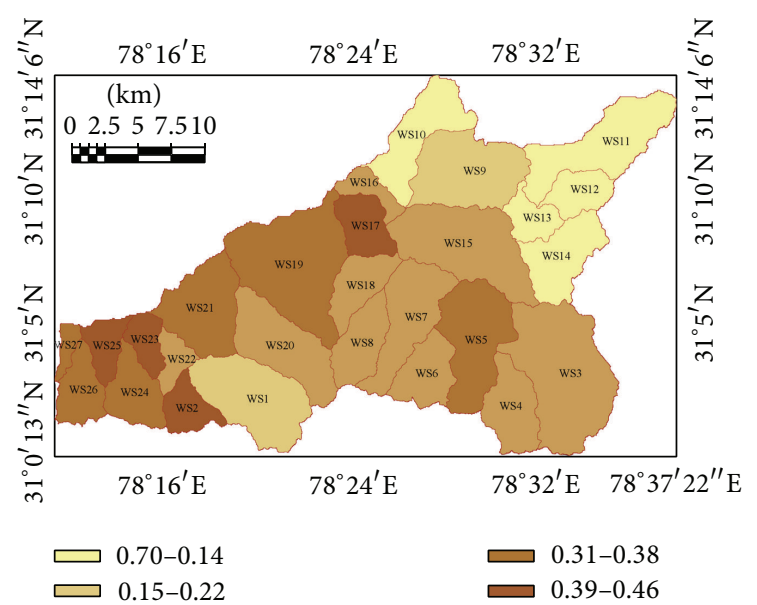

(a)

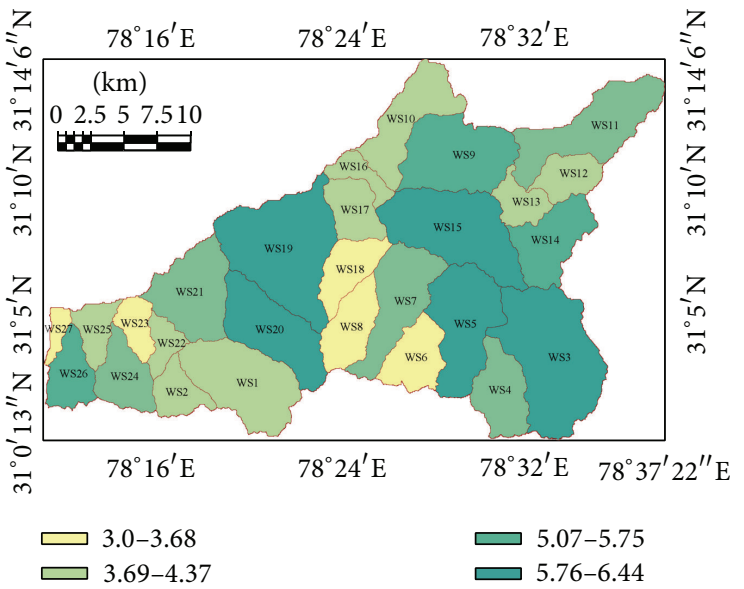

(b)

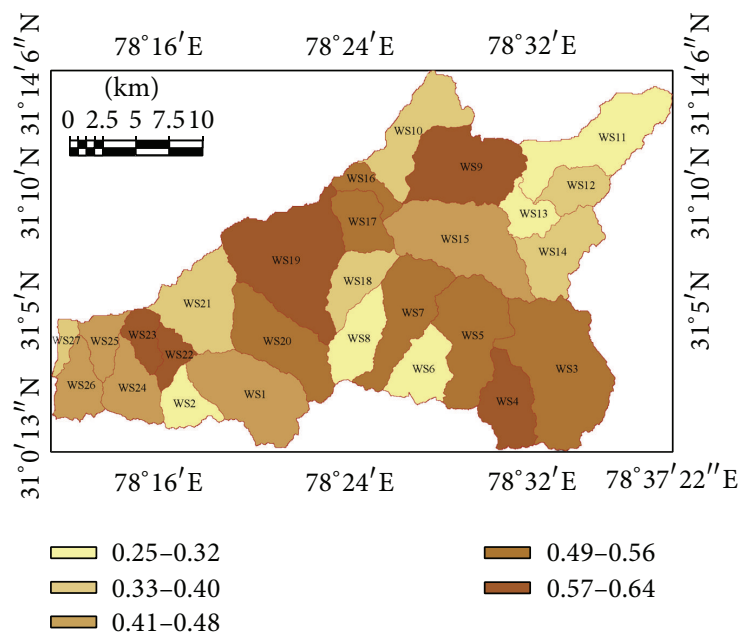

(c)

FIGURE 6: Map showing response of various parameters of relief characteristics in subwatersheds of Supin River basin. (a) Relief Ratio $\left(R_{h}\right)$. (b) Ruggedness Number $\left(R_{n}\right)$. (c) Dissection Index $\left(D_{i s}\right)$.

TABLE 4: Linear correlation among selected morphometric parameters of Supin River basin along with the calculated $t$ and corresponding $P$ values.

\begin{tabular}{lcccc}
\hline Variables $\left(x_{\text {axis }}-y_{\text {axis }}\right)$ & Linear equation & $r^{2}$ & $|t|$ & $P$ value \\
\hline Circularity ratio-compactness coefficient & $y=-0.5024 x+1.2084$ & 0.98 & 35.74 & 0 \\
Form ratio-elongation ratio & $y=1.0564 x+0.2624$ & 0.97 & 29.85 & 7.54 \\
Drainage density-stream frequency & $y=0.8838 x+0.4434$ & 0.69 & $6.89 E-08$ \\
Constant of channel maintenance-stream frequency & $y=-4.8551 x+4.3025$ & 0.71 & 7.86 & $3.27 E-08$ \\
Constant of channel maintenance-drainage density & $y=-6.0512 x+4.9628$ & 0.98 & 37.68 & 0 \\
Length of overland flow-stream frequency & $y=-0.0733 x+0.3741$ & 0.71 & 7.86 & $3.27 E-08$ \\
Length of overland flow-drainage density & $y=-0.0812 x+0.4065$ & 0.98 & 0 \\
Infiltration number-drainage density & $y=0.2144 x+1.2349$ & 0.92 & 16.90 & $3.33 E-15$ \\
Number of streams of all order-drainage texture & $y=0.021 x+0.5454$ & 0.94 & 19.11 & $2.22 E-16$ \\
Relief ratio-basin length & $y=-44.247 x+20.059$ & 0.82 & 10.53 & $1.13 E-10$ \\
Drainage texture-ruggedness number & $y=1.6296 x+2.5781$ & 0.66 & 6.91 & $3.05 E-07$ \\
\hline
\end{tabular}




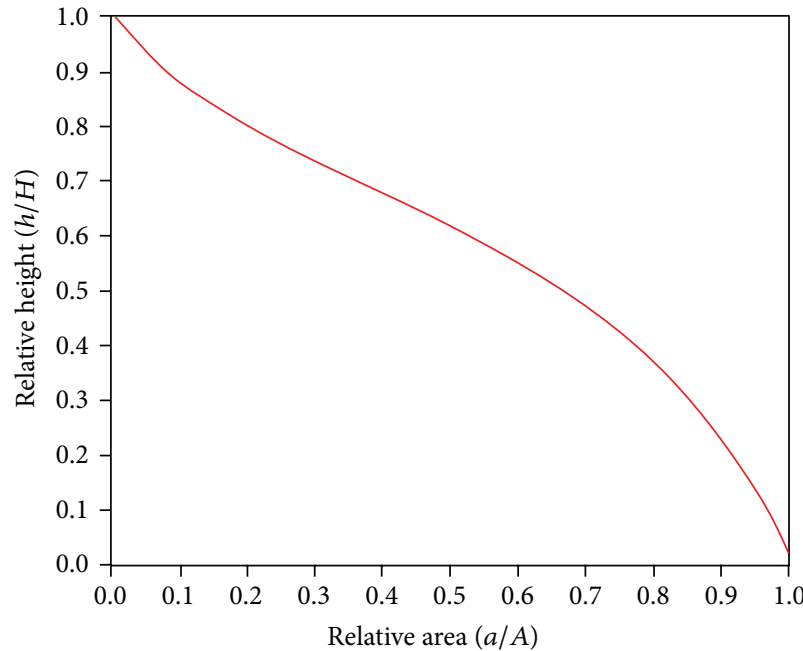

\begin{tabular}{|ccc|}
\hline \multicolumn{3}{|c|}{$\mathrm{HI}=0.58$} \\
\hline \multicolumn{3}{|c|}{ Reduced $\chi^{2}=2.87256 E-5$} \\
\hline \multicolumn{3}{|c|}{ Adjusted $R^{2}=0.99953$} \\
\hline Parameters & Value & Standard error \\
\hline$A_{0}$ & 100.62721 & 0.73249 \\
\hline$A_{1}$ & -0.44984 & 0.13586 \\
\hline$A_{2}$ & 0.00446 & 0.0083 \\
\hline$A_{3}$ & $-2.04 E-04$ & $2.07 E-04$ \\
\hline$A_{4}$ & $-3.67 E-07$ & $2.24 E-06$ \\
\hline$A_{5}$ & $1.42 E-08$ & $8.79 E-09$ \\
\hline
\end{tabular}

(a)

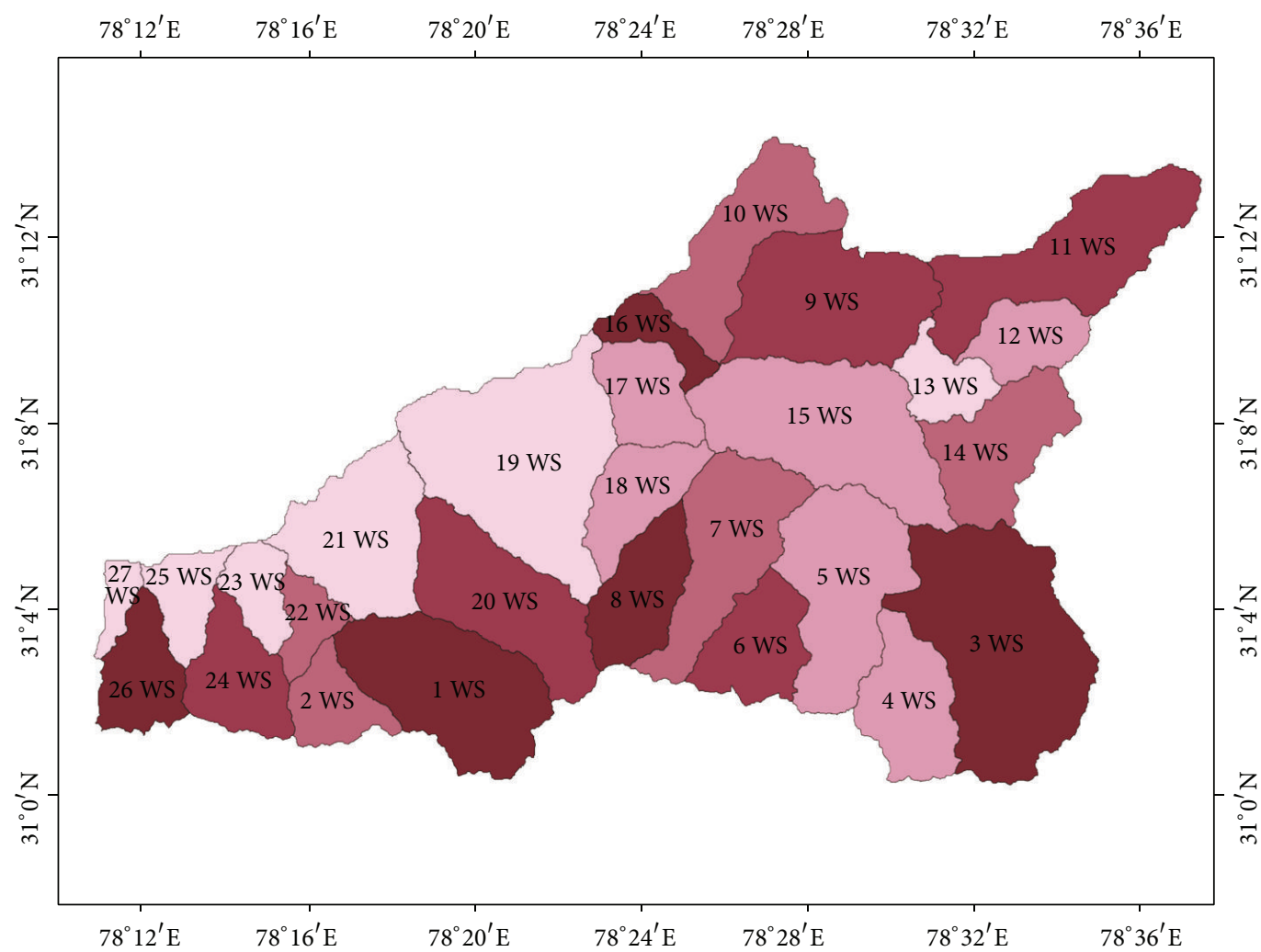

Hypsometric integral

Hypsometry

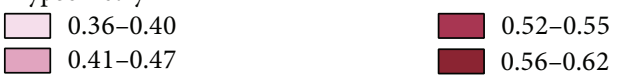

(b)

Figure 7: Analysis of hypsometric integral (HI) as an index of basin maturity. (a) Hypsometric curve of Supin River basin along with the estimated coefficients of 5th order polynomial function. (b) Thematic map showing the variation of Hypsometric Integral (HI) among the subwatersheds of Supin River basin. 
The estimated coefficients are $A_{0}, A_{1}, A_{2}, A_{3}, A_{4}$, and $A_{5}$ which can be obtained from regression of the hypsometric curve (Figure $7(\mathrm{a})$ ). The statistical moments of hypsometric curve include skewness of the hypsometric curve $(-0.474)$, kurtosis of the hypsometric curve (2.495), skewness of the hypsometric density function $(-0.413)$, and kurtosis of the hypsometric density function (2.392). These are collectively known as the derived parameters of hypsometric curve. The area below the hypsometric curve is known as the hypsometric integral (HI) and is calculated using the following formula:

$$
\mathrm{HI}=\frac{(m-l)}{(h-l)},
$$

where $\mathrm{HI}$ is hypsometric integral, $m$ is mean elevation, $h$ is maximum elevation, and $l$ is minimum elevation. HI has been calculated for all the subwatersheds of Supin River basin. The convex hypsometric curve (Figure 7(a)) of Supin River basin shows HI value of 0.58 . The HI values for the subwatersheds range from 0.36 to 0.62 (Figure $7(\mathrm{~b})$ ).

The derived parameters of hypsometric curve are sensitive to subtle changes in overall basin slope and basin development as the mass is removed by erosion over a long geological time period [59]. Present study shows that head ward development of the main stream and its tributaries produce high values for hypsometric skewness [59]. On the other hand, the density function of the curve is closely related to rates of change in overall basin slope and tendency toward geomorphic equilibrium [59]. Density skewness interprets the behaviour of slope change in the basin. Positive value of density skewness is an indication of fluvial dominance over the landforms of this region. Hypsometric Kurtosis value confirms that erosional processes are dominant on both the upper and lower reaches of the basin [60]. Mid basin slope is moderate as the density Kurtosis value is platykurtic in nature. The HI value of Supin basin (0.58) indicates that the basin is at a youthful stage of development. [6]. A few subwatersheds showing low HI values (Figure 7(b)) have attained relatively mature stage and are in a state of reaching dynamic equilibrium. Most of the subwatersheds showing high $\mathrm{HI}$ are located on the hanging wall of MCT and MT (Figures 2(b) and 7(b)) which also indicate a subsurface control on the maturity of the Supin River basin.

\section{Conclusion}

There is a structural influence on drainage development with trellised pattern being the dominant drainage pattern. Channel extension in this mountainous region takes place mainly through headward erosion which is characteristic of basins in early mature stage of development. The area is well drained by the 1st and 2nd order streams having highest drainage area which produces a rugged terrain, moderately dissected by deep incised valleys. The high relief and moderate permeability of the surface in relatively circular subwatersheds with high circularity ratio generates high runoffs which make these subwatersheds more susceptible to floods, soil erosion, and debris flow. In a few elongated subwatersheds the management of flood flow is easier because of the low side flow for shorter duration and smaller peak flows for longer duration.

Fourth and 5th order streams flowing along regional fault zones may generate landslides due to increase in the level of erosion. In addition, an increase in the incision of the streams along the weak and fractured fault zones results in increase in the sediment load of the streams which in turn may trigger flash floods. Sudden topographic breaks along the 6 th order stream profile of the basin at multiple places influence the tectonomorphic landforms developed along Supin River.

The significance of studying morphometric properties of Supin basin lies in the fact that it will help in future watershed management and hazard management studies. Due to the mountainous nature of the terrain the region suffers from frequent flash floods and landslides. Hence, such type of studies will provide knowledge and database for decision making for strategic planning and delineation of prioritised hazard management zones. Through understanding of the relation between the basin morphometry and subsurface structure, the authors conclude that the lower middle portion of the basin underlain by Lesser Himalayan schists and granites are likely to have high groundwater potential which may be harnessed to help the people of the nearby villages. Moreover, it may also help in assessing the groundwater potential of the region and delineating effective water harvesting sites. These morphometric techniques may be applied to other mountainous river basins around the globe. Morphometric analysis thus has a wider significance in watershed prioritisation and management, soil erosion studies, groundwater potential assessment, and flood hazard risk reduction in the Supin watershed that forms an important tributary of the Tons River basin.

\section{Conflict of Interests}

The authors declare that there is no conflict of interests regarding the publication of this paper.

\section{Acknowledgments}

Assistance from the postgraduate students of the Department of Geography, University of Calcutta, during field work was gratefully acknowledged. Infrastructural facilities were provided by the Department of Geology, University of Calcutta, and the Remote Sensing \& GIS Department of the Vidyasagar University. Thanks are due to Professor Sunando Bandyopadhyay, Department of Geography, University of Calcutta. Comments from the anonymous reviewers are gratefully acknowledged.

\section{References}

[1] J. I. Clarke, "Morphometry from maps," in Essays in Geomorphology, G. H. Dury, Ed., pp. 235-274, Elsevier, New York, NY, USA, 1966 .

[2] R. E. Horton, "Drainage basin characteristics," Transactions of American Geophysics Union, vol. 13, pp. 350-361, 1932. 
[3] R. E. Horton, "Erosional development of streams and their drainage basins: hydrophysical approach to quantitative morphology," Geological Society of America Bulletin, vol. 56, pp. 275370, 1945.

[4] A. N. Strahler, "Hypsometric analysis of erosional topography," Bulletin of the Geological Society of America, vol. 63, pp. 1117$1142,1952$.

[5] A. N. Strahler, "Quantitative analysis of watershed geomorphology," Transactions of American Geophysics Union, vol. 38, pp. 913-920, 1957.

[6] A. N. Strahler, "Quantitative geomorphology of drainage basin and channel networks," in Handbook of Applied Hydrology, V. T. Chow, Ed., McGraw Hill, New York, NY, USA, 1964.

[7] S. A. Schumm, "Evolution of drainage systems and slopes in badlands at Perth Amboy, New Jersey," Bulletin of the Geological Society of America, vol. 67, pp. 597-646, 1956.

[8] R. J. Chorley and M. A. Morgan, "Comparison of morphometric features, Unaka Mountains, Tennessee and North Carolina, and Dartmoor, England," Geological Society of America Bulletin, vol. 73, no. 1, pp. 17-34, 1962.

[9] P. W. Williams, "Morphometric analysis of polygonal karst in New Guinea," Geological Society of America Bulletin, vol. 83, no. 3, pp. 761-796, 1972.

[10] L. M. Mesa, "Morphometric analysis of a subtropical Andean basin (Tucumán, Argentina)," Environmental Geology, vol. 50, no. 8, pp. 1235-1242, 2006.

[11] P. Lyew-Ayee, H. A. Viles, and G. E. Tucker, "The use of GISbased digital morphometric techniques in the study of cockpit karst," Earth Surface Processes and Landforms, vol. 32, no. 2, pp. 165-179, 2007.

[12] T. B. Altin and B. N. Altin, "Development and morphometry of drainage network in volcanic terrain, Central Anatolia, Turkey," Geomorphology, vol. 125, no. 4, pp. 485-503, 2011.

[13] M. Buccolini, L. Coco, C. Cappadonia, and E. Rotigliano, "Relationships between a new slope morphometric index and calanchi erosion in northern Sicily, Italy," Geomorphology, vol. 149-150, pp. 41-48, 2012.

[14] S. S. Vittala, S. Govindaih, and H. H. Gowda, "Morphometric analysis of sub-watershed in the Pavada area of Tumkur district, South India, using remote sensing and GIS techniques," Journal of Indian Society of Remote Sensing, vol. 32, no. 4, pp. 351-362, 2004.

[15] R. Chopra, R. D. Dhiman, and P. K. Sharma, "Morphometric analysis of sub-watersheds in Gurdaspur district, Punjab using remote sensing and GIS techniques," Journal of Indian Society of Remote Sensing, vol. 33, no. 4, pp. 531-539, 2005.

[16] H. Vijith and R. Sateesh, "GIS based morphometric analysis of two major upland sub-watersheds of Meenachil river in Kerala," Journal of the Indian Society of Remote Sensing, vol. 34, no. 2, pp. 181-185, 2006.

[17] M. Rudraiah, S. Govindaiah, and S. S. Vittala, "Morphometry using remote sensing and GIS techniques in the sub-basins of Kagna river basin, Gulburga district, Karnataka, India," Journal of the Indian Society of Remote Sensing, vol. 36, no. 4, pp. 351360, 2008.

[18] M. Bagyaraj and B. Gurugnanam, "Significance of morphometry studies, soil characteristics, erosion phenomena and landform processes using remote Sensing and GIS for Kodaikanal Hills, a global biodiversity hotpot in Western Ghats, Dindigul District, Tamil Nadu, South India," Research Journal of Environmental and Earth Sciences, vol. 3, no. 3, pp. 221-233, 2011.
[19] I. Malik, S. Bhat, and N. A. Kuchay, "Watershed based drainage morphometric analysis of Lidder catchment in Kashmir valley using Geographical Information System," Recent Research in Science and Technology, vol. 3, no. 4, pp. 118-126, 2011.

[20] J. Thomas, S. Joseph, K. P. Thrivikramji, and G. Abe, "Morphometric analysis of the drainage system and its hydrological implications in the rain shadow regions, Kerala, India," Journal of Geographical Sciences, vol. 21, no. 6, pp. 1077-1088, 2011.

[21] N. S. Magesh, K. V. Jitheshlal, N. Chandrasekar, and K. V. Jini, "GIS based morphometric evaluation of Chimmini and Mupily watersheds, parts of Western Ghats, Thrissur District, Kerala, India," Earth Science Information, vol. 5, no. 2, pp. 111-121, 2012.

[22] P. Singh, J. K. Thakur, and U. C. Singh, "Morphometric analysis of Morar River Basin, Madhya Pradesh, India, using remote sensing and GIS techniques," Environmental Earth Science, vol. 68, no. 7, pp. 1967-1977, 2012.

[23] K. Pareta and U. Pareta, "Quantitative geomorphological analysis of a watershed of Ravi River Basin, H.P. India," International Journal of Remote Sensing and GIS, vol. 1, no. 1, pp. 41-56, 2012.

[24] S. K. Nag and S. Chakraborty, "Influence of rock types and structures in the development of drainage network in hard rock area," Journal of Indian Society of Remote Sensing, vol. 31, no. 1, pp. 25-35, 2003.

[25] J. D. Das, Y. Shujat, and A. K. Saraf, "Spatial technologies in deriving the morphotectonic characteristics of tectonically active Western Tripura Region, Northeast India," Journal of the Indian Society of Remote Sensing, vol. 39, no. 2, pp. 249-258, 2011.

[26] R. Bali, K. K. Agarwal, S. Nawaz Ali, S. K. Rastogi, and K. Krishna, "Drainage morphometry of Himalayan Glaciofluvial basin, India: hydrologic and neotectonic implications," Environmental Earth Sciences, vol. 66, no. 4, pp. 1163-1174, 2012.

[27] A. Demoulin, "Basin and river profile morphometry: a new index with a high potential for relative dating of tectonic uplift," Geomorphology, vol. 126, no. 1-2, pp. 97-107, 2011.

[28] P. D. Sreedevi, K. Subrahmanyam, and S. Ahmed, "The significance of morphometric analysis for obtaining groundwater potential zones in a structurally controlled terrain," Environmental Geology, vol. 47, no. 3, pp. 412-420, 2005.

[29] K. Narendra and K. N. Rao, "Morphometry of the Meghadrigedda watershed, Visakhapatnam District, Andhra Pradesh using GIS and Resourcesat data," Journal of Indian Society of Remote Sensing, vol. 34, no. 2, pp. 102-110, 2006.

[30] K. Avinash, K. S. Jayappa, and B. Deepika, "Prioritization of subbasins based on geomorphology and morphometricanalysis using remote sensing and geographic informationsystem (GIS) techniques," Geocarto International, vol. 26, no. 7, pp. 569-592, 2011.

[31] A. Mishra, D. P. Dubey, and R. N. Tiwari, "Morphometric analysis of Tons basin, Rewa District, Madhya Pradesh, based on watershed approach," Earth Science India, vol. 4, no. 3, pp. 171-180, 2011.

[32] I. Jasmin and P. Mallikarjuna, "Morphometric analysis of Araniar river basin using remote sensing and geographical information system in the assessment of groundwater potential," Arab Journal of Geosciences, vol. 6, no. 10, pp. 3683-3692, 2013.

[33] A. Javed, M. Y. Khanday, and S. Rais, "Watershed prioritization using morphometric and land use/land cover parameters: a remote sensing and GIS based approach," Journal of the Geological Society of India, vol. 78, no. 1, pp. 63-75, 2011. 
[34] P. C. Patton and V. R. Baker, "Morphometry and floods in small drainage basins subject to diverse hydrogeomorphic controls," Water Resources Research, vol. 12, no. 5, pp. 941-952, 1976.

[35] M. Diakakis, "A method for flood hazard mapping based on basin morphometry: application in two catchments in Greece," Natural Hazards, vol. 56, no. 3, pp. 803-814, 2011.

[36] H. B. Wakode, D. Dutta, V. R. Desai, K. Baier, and R. Azzam, "Morphometric analysis of the upper catchment of Kosi River using GIS techniques," Arabian Journal of Geosciences, vol. 6, no. 2, pp. 395-408, 2011.

[37] S. A. Romshoo, S. A. Bhat, and I. Rashid, "Geoinformatics for assessing the morphometric control on hydrological response at watershed scale in the Upper Indus basin," Journal of Earth System Science, vol. 121, no. 3, pp. 659-686, 2012.

[38] A. Yin, "Cenozoic tectonic evolution of the Himalayan orogen as constrained by along-strike variation of structural geometry, exhumation history, and foreland sedimentation," Earth-Science Reviews, vol. 76, no. 1-2, pp. 1-131, 2006.

[39] K. S. Valdiya, Geology of the Kumaon Lesser Himalaya, Wadia Institute of Himalaya, Uttarakhand, India, 1980.

[40] P. Srivastava and G. Mitra, "Thrust geometries and deep structure of the outer and lesser Himalaya, Kumaon and Garhwal (India): implications for evolution of the Himalayan fold-andthrust belt," Tectonics, vol. 13, no. 1, pp. 89-109, 1994.

[41] P. G. DeCelles, G. E. Gehrels, J. Quade, and T. P. Ojha, "Eoceneearly Miocene foreland basin development and the history of Himalayan thrusting, western and central Nepal," Tectonics, vol. 17, no. 5, pp. 741-765, 1998.

[42] P. G. DeCelles, D. M. Robinson, and G. Zandt, "Implications of shortening in the Himalayan fold-thrust belt for uplift of the Tibetan Plateau," Tectonics, vol. 21, no. 6, pp. 1-25, 2002.

[43] O. N. Pearson and P. G. DeCelles, "Structural geology and regional tectonic significance of the Ramgarh thrust, Himalayan fold-thrust belt of Nepal," Tectonics, vol. 24, no. 4, Article ID TC4008, pp. 1-26, 2005.

[44] N. McQuarrie, D. Robinson, S. Long et al., "Preliminary stratigraphic and structural architecture of Bhutan: implications for the along strike architecture of the Himalayan system," Earth and Planetary Science Letters, vol. 272, no. 1-2, pp. 105-117, 2008.

[45] J. C. Vannay and B. Grasemann, "Himalayan inverted metamorphism and syn-convergence extension as a consequence of a general shear extrusion," Geological Magazine, vol. 138, no. 3, pp. 253-276, 2001.

[46] K. S. Valdiya, "Reactivation of terrane-defining boundary thrusts in central sector of the Himalaya: implications," Current Science, vol. 81, no. 11, pp. 1418-1431, 2001.

[47] R. Kumar, S. K. Ghosh, R. K. Mazari, and S. J. Sangode, "Tectonic impact on the fluvial deposits of Plio-Pleistocene Himalayan foreland basin, India," Sedimentary Geology, vol. 158, no. 3-4, pp. 209-234, 2003.

[48] H. K. Sachan, M. J. Kohn, A. Saxena, and S. L. Corrie, "The Malari leucogranite, Garhwal Himalaya, Northern India: chemistry, age, and tectonic implications," Bulletin of the Geological Society of America, vol. 122, no. 11-12, pp. 1865-1876, 2010.

[49] J. E. Mueller, "An introduction to the hydraulic and topographic sinuosity indexes," Annals of the Association of American Geographers, vol. 58, no. 2, pp. 371-385, 1968.

[50] H. Gravelius, Flusskunde, Goschen'sche Verlagshandlung, Berlin, Germany, 1941.

[51] M. A. Melton, An Analysis of the Relations among Elements of Climate, Surface Properties and Geomorphology, Columbia University, New York, NY, USA, 1957.
[52] J. S. Smart and A. J. Surkan, "The relation between mainstream length and area in drainage basins," Water Resources Research, vol. 3, no. 4, pp. 963-974, 1967.

[53] P. E. Black, "Hydrograph responses to geomorphic model watershed characteristics and precipitation variables," Journal of Hydrology, vol. 17, no. 4, pp. 309-329, 1972.

[54] A. Faniran, "The index of drainage intensity -a provisional new drainage factor," Australian Journal of Science, vol. 31, pp. 328$330,1968$.

[55] S. Singh and A. Dubey, Geo-environmental Planning of Watersheds in India, vol. 28, Chugh, Allahabad, India, 1994.

[56] S. Singh and M. C. Singh, "Morphometric analysis of Kanhar river basin," National Geographical Journal of India, vol. 43, no. 1, pp. 31-43, 1997.

[57] D. Waugh, Geography, An Integrated Approach, Nelson, New York, NY, USA, 1995.

[58] J. M. Harlin, "Statistical moments of the hypsometric curve and its density function," Journal of the International Association for Mathematical Geology, vol. 10, no. 1, pp. 59-72, 1978.

[59] J. M. Harlin, "The effect of precipitation variability on drainage basin morphometry," American Journal of Science, vol. 280, no. 8, pp. 812-825, 1980.

[60] W. Luo, "Quantifying groundwater-sapping landforms with a hypsometric technique," Journal of Geophysical Research E: Planets, vol. 105, no. 1, pp. 1685-1694, 2000. 

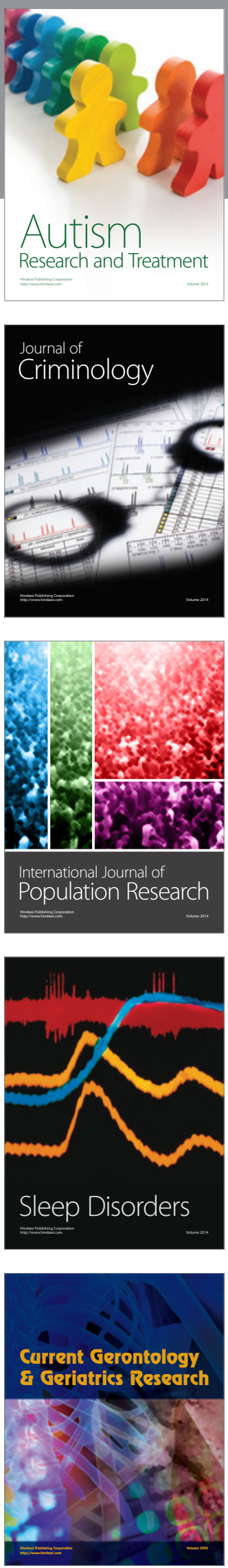
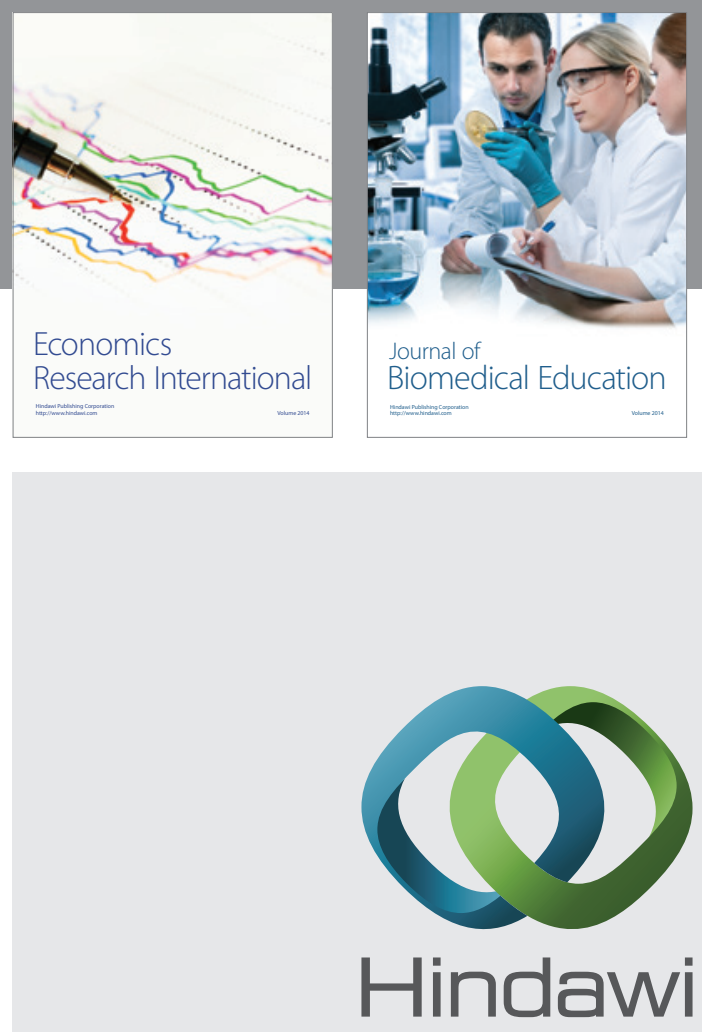

Submit your manuscripts at

http://www.hindawi.com
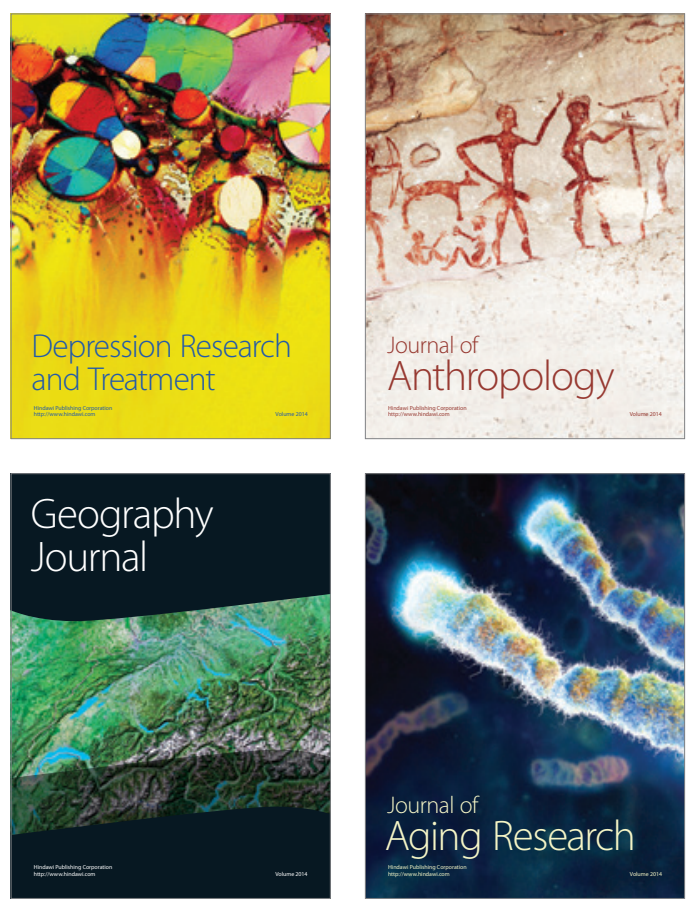
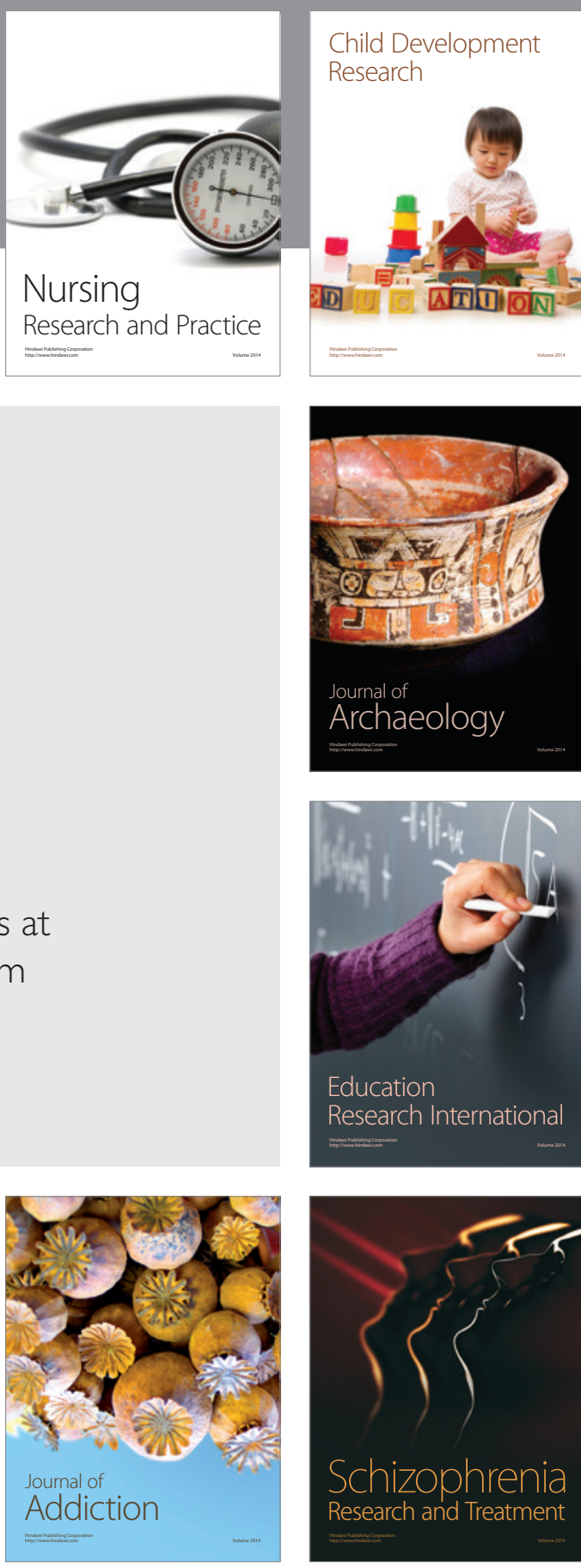

(D)
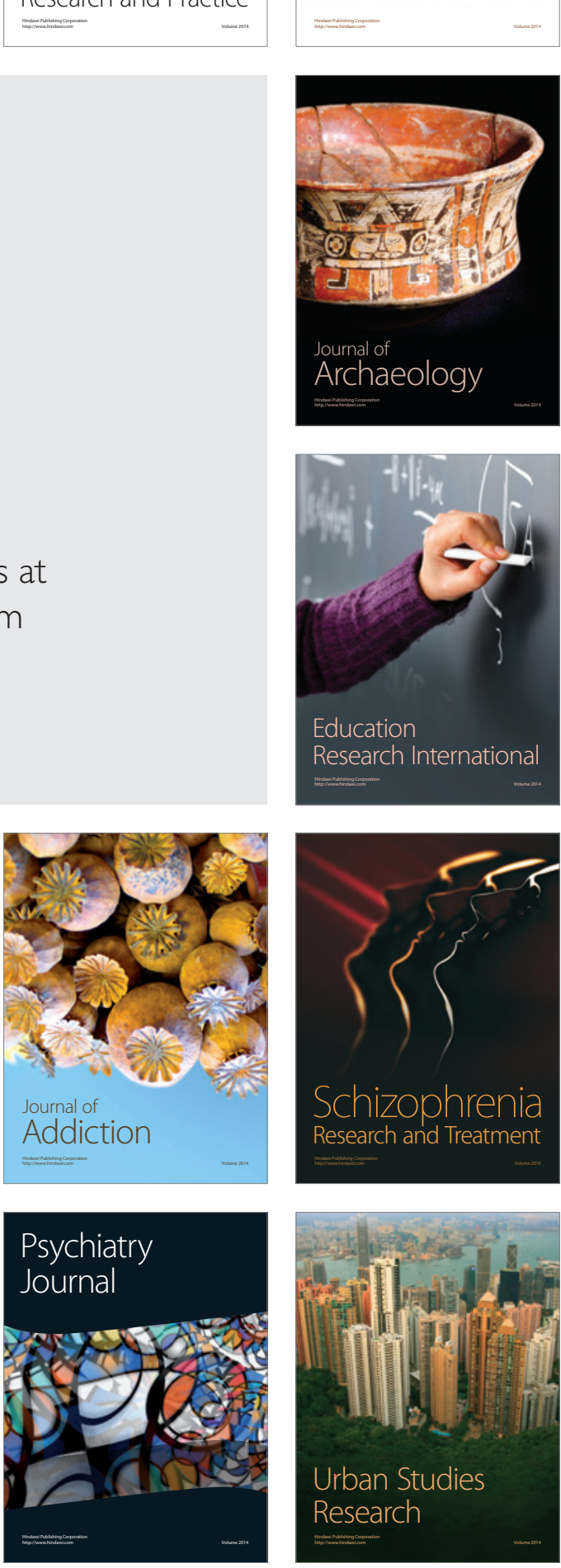